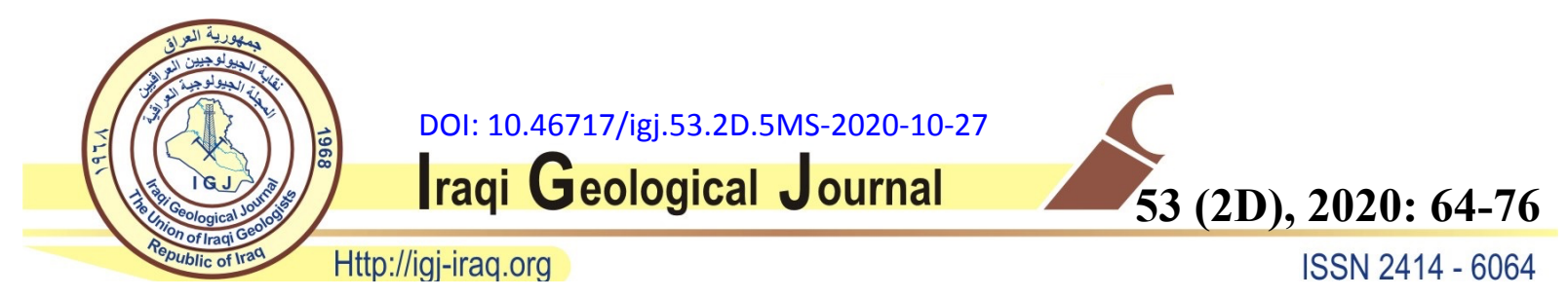

\title{
HEALTH RISK OF ZINC POLLUTANT IN AGRICULTURAL SOIL IN SOME LEAVES OF SELECTED LEAFY VEGETABLES IN KIRKUK, NORTH IRAQ
}

\author{
${ }^{1}$ Hassan A. A. Al-Jumaily And ${ }^{1}$ Eman W.W. Al-Berzanje* \\ ${ }^{1}$ Department of Applied Geology, College of Science, University of Kirkuk, Iraq \\ *E-mail: Emanalberzanje@gmail.com \\ Received: 8 August 2020; accepted: 12 September 2020
}

\begin{abstract}
Evaluation of the environmental geochemistry needs studying element content in different environmental profiles, for that reason the zinc content has been studied in the soil-plant to fill gaps in Kirkuk City. Ten soil samples (L1-L10) are collected from agricultural fields (0$20 \mathrm{~cm}$ depth), with twelve leafy vegetable samples for four types, and each type has three samples: celery (N1, N2, N3), basil (N4, N5, N6), cress (N7, N8, N9), and arugula (N10, N11, N12) from the fields $(L 2, L 7, L 8)$ which the soil sample were chosen. Samples were analyzed using ICP-MS technique. The results show the average concentration value of $\mathrm{Zn}$ in soil samples is $70.91 \mathrm{mg} / \mathrm{kg}$ the highest concentration is recorded in sample $\mathrm{L} 7(169.2 \mathrm{mg} / \mathrm{kg})$, whereas in the plant samples the highest average of $Z n$ was found in cress 67.73> basil 52.53> arugula 38.9> celery $29.3 \mathrm{in} \mathrm{mg} / \mathrm{kg}$, respectively. Transfer factor value showed that the highest value in Cress 0.729> TF Basil 0.612> TF Arugula 0.511> TF Celery 0.395, respectively. Igeo result values show that all soil sampling sites are unpolluted with $\mathrm{Zn}$, except $L 7$ is unpolluted to moderate with Igeo value (0.8). The contamination factor values in L7, L8, L9, L10 samples (2.603, 1.284, 1.086 and 1.129) refers to a moderate contamination level with Zn. Target hazard quotient values for children $>1$ in samples N4, $\mathrm{N5}, \mathrm{N7}, \mathrm{N8}, \mathrm{N9}, \mathrm{N10}$, and target hazard quotient values for adult $>1$ in samples N5, N8, N9, that indicate they are exposed to different health effects. The increase in the concentration of the $\mathrm{Zn}$ in soils is due to irrigated field crops with wastewater, and through it, the plant absorbs it by root depending on the type of plant, the location of the sample, and the soil properties.
\end{abstract}

Keywords: Zinc; Transfer factor; Leafy vegetable; Pollution level; Health risk assessment

\section{INTRODUCTION}

Zinc (Zn) is a chemical element discovered by German scientist Andreas Marggraf in 1974 (Heiserman, 1992), the geochemical principles for it is located in period four and group twelve 
in the periodic table, with atomic number 30, atomic mass 65.38, atomic radius $153 \mathrm{pm}$, and density $7.13 \mathrm{gm} / \mathrm{cm}^{3}$ (Reimann and Caritat, 1998 and Kabata- Pendias, 2011). Contamination with heavy elements in worldwide has disrupted the environment and causes health impact and risks to humans (Rai et al., 2019). Nu et al. (2020) mentioned that soil salinization is a serious problem that restricts agricultural productivity worldwide due to climate change. A heavy element including zinc is accumulating in the top layer of the soils (Kooner et al., 2014). Soil is an important basin for many nutrients and pollutants in it, which plays an important role in environmental and social safety and stability ( $\mathrm{Wu}$ et al., 2018). In an uncontaminated environment with zinc source is from weathering source rocks, deposition from the atmosphere, agricultural fertilizers, and accumulates over time (Imseng et al., 2019). Continuous increase in the levels of heavy elements in the soil results from practices agricultural and anthropogenic sources (Baltas et al., 2019). The most important anthropogenic that release the $\mathrm{Zn}$ to the environment are the wastewater, fertilizers, pesticide (Mičijević et al., 2019), Where absorption the $\mathrm{Zn}$ from soil and water by root tissue and transferred it to other parts of leafy vegetables (Gupta et al., 2019), that transferred to plant in form of $\mathrm{Zn}^{+2}$ or organic acids (Hefferon, 2019), and available for absorption by ionic exchange (Gupta et al., 2016), it occurs as a natural constituent in plant tissues (WHO/FAO, 2017), and it is a major micronutrient and necessary for the natural growth of agricultural crops (Akhtar et al., 2019), it participates in several major physiological functions as formation of chlorophyll, structure of membrane, immunity against drought, disease and photosynthesis (Noulas et al., 2018). The high concentrations of Zn may cause toxic for plants and microorganisms that live in the soil and this in turn has an impact on human health (Alloway, 2013). Al-Hamadani et al., 2016 mentioned that the organic fraction in Kirkuk soil contained the next significantly portion of metals, with the following decreasing order: $\mathrm{Cd}, \mathrm{V}, \mathrm{Ag}, \mathrm{Cu}$ and $\mathrm{Cr}$ whereas Fe-Mn oxide fraction was contained high levels of $\mathrm{Zn}$ and Co. $\mathrm{Cd}$ and $\mathrm{Pb}$ occupied the important portion of carbonate fraction. With the exception of residual fractions, most metal fractions decrease with soil profiles, but there are some metal such as $\mathrm{Ag}, \mathrm{Zn}$ and $\mathrm{V}$ increase. The main pathway of human exposure to $\mathrm{Zn}$ is via eating vegetables (Akande and Ajayi, 2017). In wise of human health, $\mathrm{Zn}$ is one of the most important trace elements for organism (WHO/FAO, 2017), it has three biological roles: organizational, structural, and catalytic (Akhtar et al., 2019 and Chasapis et al., 2012). Zinc is essential for neurological, immune system function, DNA and protein synthesis, cell growth and division, male and female reproduction (Alloway, 2013), and has an important role in taste acuity, blood clotting, wound healing, sperm production, fetal growth, bone hardening, and thyroid gland functions (Chasapis et al., 2012), it also stimulates growth, height, weight, smell, appetite, 
vision, skin, and hair (Das and Green, 2016). Zinc is available in all tissues, cells and fluids in human body and estimated around 2 gm (Das and Green, 2016 and FAO/WHO, 2001) in lung it is $10 \mathrm{mg} / \mathrm{kg}$ and in liver equals to $57 \mathrm{mg} / \mathrm{kg}$ (Kabata-Pendias and Mukherjee, 2007). The Zn average daily intake has been estimated for adults by food chain to be maximally $20 \mathrm{mg} / \mathrm{d}$, if the taken dose more than 4-8 gm, may cause poisoning with main symptoms are vomiting, nausea, diarrhea, and fever (, 2017). There is an urgent need to assess the soil pollution with heavy element and determine their sources to meet the risks that they cause on soil quality, food safety and human health (Ren et al., 2019). The aims of the current study are determination the concentration of zinc in agricultural soil and leafy vegetable samples (Celery, Cress, Basil, Arugula) in agricultural field crops, determine transfer factor (TF) of leafy vegetables of zinc from soil to plant, pollution assessment of $\mathrm{Zn}$ in soil samples, and Assessing the health risks of zinc for children and adults via their consumption of leafy vegetables in the Kirkuk city.

\section{MATERIALS AND METHODES}

\section{Location of Study Area}

The study area Kirkuk city is located $250 \mathrm{Km}$ north of the capital city Baghdad, between

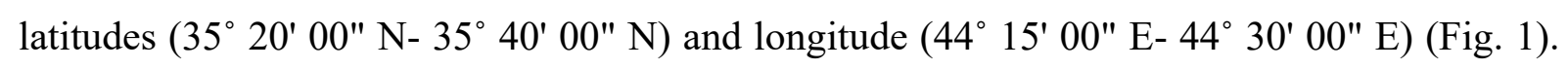
The sides of Al Khassa River are used for growth crops there, the sampling site position coordinates recorded by GPS (Global Position System) (Table 1).

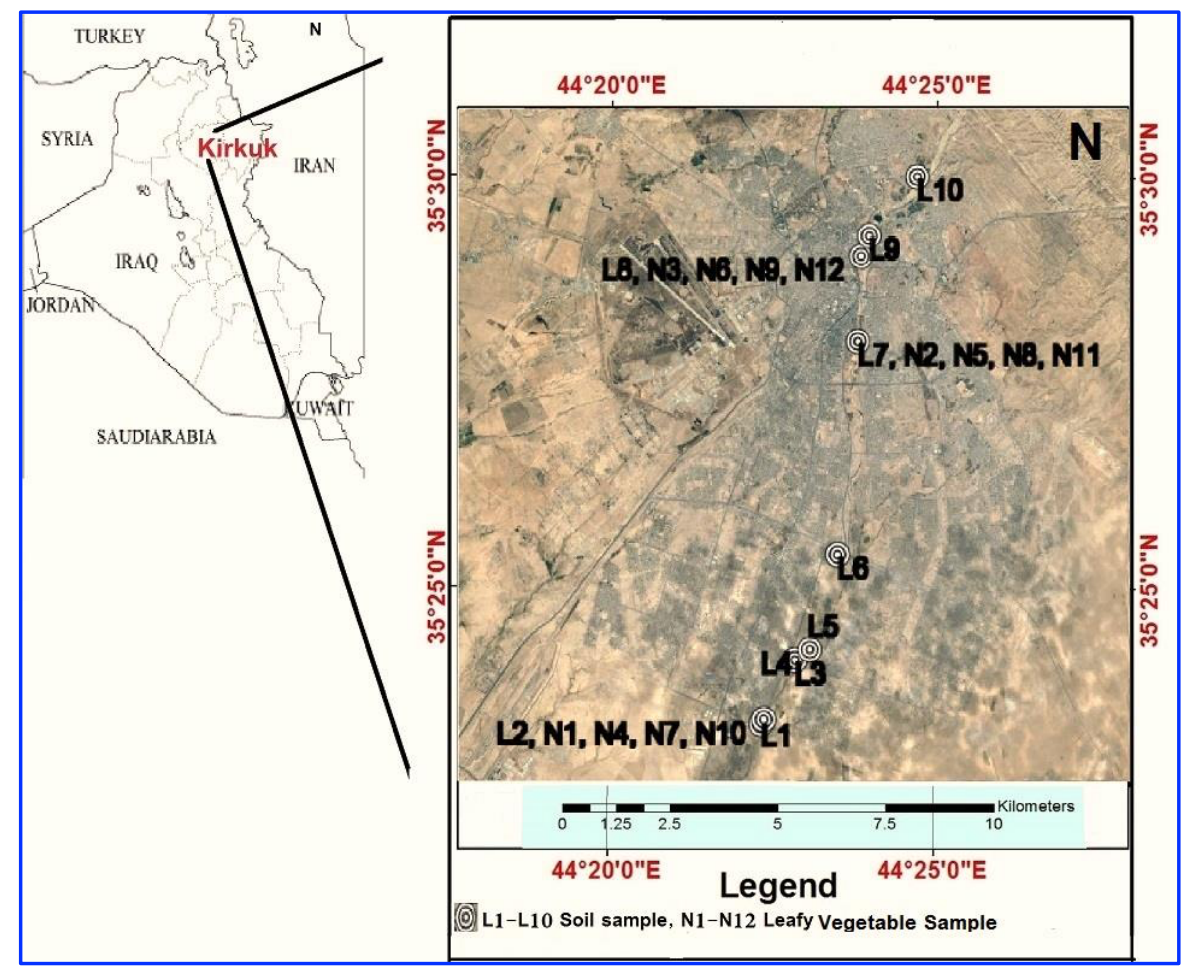

Fig. 1. Location of study area and distribution of sample points (Arc GIS) 


\section{Sample Preparation}

Ten agricultural bulk soil samples are selected from study area crop fields, and collected from 0-20 cm depth across selected sites throughout the study area in September 2019 by using auger, they are kept in closed bags with written sample symbol on them. Totally twelve leafy vegetables samples are collected from three different fields with three sample for each four kinds of plant Celery, Basil, Cress and Arugula, and coding each sample from vegetables. These plant samples were selected from soil sampling sites (L2, L7, L8) (Table 1) (Fig. 1). The vegetables were chosen for their abundant in the study area and consumed by local population, that irrigated from $\mathrm{Al}$ Khassa river water, which is a seasonal river that sewage water flows into, the soil and vegetable samples were collected from those fields that distributed on both sides of Khassa River. The preparation of all collected bulk soil samples (mixture of irregularly sized fraction granules) include drying it in room temperature then grinding and sifting the samples through a sieve with $2 \mathrm{~mm}$ mesh size, then stored in polyethylene bags until further laboratory analysis. While, vegetable samples were washed by distilled water, dried at room temperature and then saved in polythene bags. Thus, all the samples for both of soil and plant are prepared according to the laboratory requirements and being ready for chemical analysis to determine zinc concentration using an Inductively Coupled Plasma-Mass Spectrometer (ICPMS) technique at Acme Laboratory in Canada.

Table 1. Coordinate's and symbols for collected soil and leafy vegetable samples

\begin{tabular}{|c|c|c|c|c|}
\hline \multicolumn{3}{|c|}{ Samples } & \multicolumn{2}{|c|}{ Location } \\
\hline Number & Type & Location & Lat. & Long. \\
\hline L1 & Soil & Near Lilan Bridge & N35 $23^{\prime} 24^{\prime \prime}$ & $\mathrm{E} 44^{\circ} 21^{\prime} 44^{\prime \prime}$ \\
\hline $\mathrm{L} 2$ & Soil & \multirow{2}{*}{ Opposite to 1st of March district } & \multirow{2}{*}{$\mathrm{N} 35^{\circ} 23^{\prime} 47^{\prime \prime}$} & \multirow{2}{*}{$\mathrm{E} 44^{\circ} 22^{\prime} 02^{\prime \prime}$} \\
\hline N1, N4, N7, N10 & Plant & & & \\
\hline L3 & Soil & Behind galaxy hall & $\mathrm{N} 35^{\circ} 24^{\prime} 07^{\prime \prime}$ & $\mathrm{E} 44^{\circ} 22^{\prime} 21^{\prime \prime}$ \\
\hline L4 & Soil & Opposite to Aden district & $\mathrm{N} 35^{\circ} 24^{\prime} 20^{\prime \prime}$ & $\mathrm{E} 44^{\circ} 22^{\prime} 43^{\prime \prime}$ \\
\hline L5 & Soil & Opposite to life fitness hall & $\mathrm{N} 35^{\circ} 24^{\prime} 42^{\prime \prime}$ & $\mathrm{E} 44^{\circ} 22^{\prime} 53^{\prime \prime}$ \\
\hline L6 & Soil & Opposite to Almualmeen district & $\mathrm{N} 35^{\circ} 25^{\prime} 05^{\prime \prime}$ & $\mathrm{E} 44^{\circ} 23^{\prime} 03^{\prime \prime}$ \\
\hline L7 & Soil & \multirow{2}{*}{ Opposite to Almansour mosque } & \multirow{2}{*}{$\mathrm{N} 35^{\circ} 27^{\prime} 30^{\prime \prime}$} & \multirow{2}{*}{$\mathrm{E} 44^{\circ} 23^{\prime} 26^{\prime \prime}$} \\
\hline $\mathrm{N} 2, \mathrm{~N} 5, \mathrm{~N} 8, \mathrm{~N} 11$ & Plant & & & \\
\hline L8 & Soil & \multirow{2}{*}{ Behind AL rehab games city } & \multirow{2}{*}{$\mathrm{N} 35^{\circ} 28^{\prime} 25^{\prime \prime}$} & \multirow{2}{*}{$\mathrm{E} 44^{\circ} 23^{\prime} 34^{\prime \prime}$} \\
\hline N3, N6, N9, N12 & Plant & & & \\
\hline L9 & Soil & Behind Imam qasim footbridge & N35 $28^{\prime} 38^{\prime \prime}$ & $\mathrm{E} 44^{\circ} 23^{\prime} 40^{\prime \prime}$ \\
\hline L10 & Soil & Sarchnar & N35 29' 14" & $\mathrm{E} 44^{\circ} 24^{\prime} 35^{\prime \prime}$ \\
\hline
\end{tabular}

\section{Transfer Factor of Zinc}

The most important paths that human exposure to health risk from diet are transfer of heavy metals from soil to plant tissue (Jolly et al., 2013), and this transfer of the element from soil to plant is measured by transfer factor (TF), where it is an indicator for assessing the movement 
of heavy metal, and its value varies depending on the environment and type of plant (CervantesTrejo et al., 2018). TF is used to assess the potential ability of the plant to transfer the elements from soil to the plant edible tissues (Proshad et al., 2019). Transfer factor of $\mathrm{Zn}$ from agricultural soil-leafy vegetables samples were calculated as follow equation (Harrison and Chirgawi, 1989 and Cui et al., 2004):

$$
\mathrm{TF}=\frac{\mathrm{C} \text { plant }(\text { dry wt) }}{\mathrm{C} \text { soil }(\text { dry wt) }}
$$

Where, $\mathrm{C}$ plant and $\mathrm{C}$ soil are representing the zinc concentration in the edible part of plant tissue $(\mathrm{mg} / \mathrm{kg}) /$ zinc concentration in soil $(\mathrm{mg} / \mathrm{kg})$ dry weight basis respectively, from where the plant was grown (Harrison and Chirgawi, 1989). The ratio of $\mathrm{TF}>1$, indicate that plants are enriched in the element and accumulate the element in edible parts (Rehman et al., 2017), TF 1 indicate uniformity in the absorption process and transport the elements to the plant, and the ratio of $\mathrm{TF}<1$ indicate that plants excluding the elements from absorption (Olowoyo et al., 2010).

\section{Pollution Assement of Zinc in Soil Samples}

The geo-accumulation index $\left(\mathrm{I}_{\text {geo }}\right)$ is used to evaluate pollution of heavy elements in soil and sediments (Adimalla and Wang, 2018), where calculated by follow equation that introduced by (Müller, 1986):

$$
\mathrm{I}_{\text {geo }}=\log _{2}\left[\frac{\mathrm{Cn}}{1.5 * \mathrm{~GB}}\right]
$$

Where, $\mathrm{Cn}$ is the measured concentration of individual heavy element ( $\mathrm{Zn})$ in soil $(\mathrm{mg} / \mathrm{kg}) ; 1.5$ is the multiplication factor reduces the effect of possible variation of lithogenic effects in the background value (Müller, 1986); GB represent geochemical background of elements in earth crust, which is $65 \mathrm{mg} / \mathrm{kg}$ for zinc according to Wedephol (1995). According to Müller (1986), the Igeo index for each metal consists of seven grades as: unpolluted ( $\mathrm{I}_{\text {geo }} \leq$ $0)$; unpolluted to moderately polluted $\left(0<\mathrm{I}_{\text {geo }}<1\right)$; moderately polluted $\left(1<\mathrm{I}_{\text {geo }}<2\right)$; moderately to strongly polluted $\left(2<\mathrm{I}_{\text {geo }}<3\right)$; strongly polluted $\left(3<\mathrm{I}_{\text {geo }}<4\right)$; strongly to extremely polluted $\left(4<\mathrm{I}_{\text {geo }}<5\right)$ and extremely polluted $\left(5<\mathrm{I}_{\text {geo }}\right)$.

Contamination factor $\left(C_{f}\right)$ is individual index utilized to evaluate soil contamination by Håkanson (1980) according to follows equation:

$$
C_{f}=\frac{C_{n}}{C_{B G}}
$$


Where, $C_{n}$ is the measured content of zinc in soil $(\mathrm{mg} / \mathrm{kg}) ; C_{B G}$ represents pre-industrial element concentration, and in general the elements concentration in the earth's crust is compensated as element concentration before the influence of industrial processes (Loska et al., 2004), which is $65 \mathrm{mg} / \mathrm{kg}$ for zinc (Wedepohl, 1995). Where $C_{f}$ value is classified into five contamination classes according to Håkanson (1980): low contamination $\left(C_{f}<1\right)$; moderate contamination factor $\left(1 \leq C_{f}<3\right)$; considerable contamination factor $\left(3 \leq C_{f}<6\right)$ and very high contamination factor $\left(6 \leq C_{f}\right)$.

\section{Health Risk Assessment of Zinc in Leafy Vegetables}

The health risks of heavy metal via consumption of leafy vegetables by local inhabitants were assessed by target hazard quotient (THQ) (Wang et al., 2005). The THQ was determined based on methods by Chien et al. (2002), that described as follows equation:

$$
T H Q=\frac{\mathrm{Ci} * \mathrm{Ef} * \mathrm{Ed} * \mathrm{VI}}{\mathrm{W} * \mathrm{Ta} * \mathrm{Rfd}}
$$

Where, $\mathrm{Ci}$ is the zinc concentration in leafy vegetables $(\mathrm{mg} / \mathrm{kg})$; Ef is the exposure frequency (350 days/yr); Ed is the exposure duration (70 yr); VI is the vegetable ingestion rate for children and adult $(0.232 \mathrm{~kg} /$ person/day) $(0.345 \mathrm{~kg} /$ person/day) respectively (Wang et al., $2005)$; $\mathrm{W}$ is the average body weight $(32.7 \mathrm{~kg})$ for children and $(55.9 \mathrm{~kg})$ for adults as used in previous researches (Wang et al., 2005); Ta is the noncarcinogens average time (Ed*365 day/yr); $\mathrm{Rfd}$ is the oral reference dose, $(\mathrm{Zn}=0.3 \mathrm{mg} / \mathrm{kg} / \mathrm{day})$ (Chien et al., 2002). If value is less than one $(T H Q<1)$ that means the population haven't exposed to health effects (Wang et al., 2005 and Chien et al., 2002), while, if THQ value is equal to or greater than one (THQ $\geq 1$ ) that means there are potential health risks from exposure and must be taken deterrent to her (Islam et al., 2014 and Adedokun et al., 2016).

\section{RESULTS AND DISCUSSION}

\section{Zinc Content in Soils and Vegetables}

The concentration of zinc in the study area agricultural soils $(\mathrm{mg} / \mathrm{kg})$ is presented in Table 2 . Total $\mathrm{Zn}$ content ranges from 48.1-169.2 $\mathrm{mg} / \mathrm{kg}$. Mean of $\mathrm{Zn}$ concentration in soils equals to $70.91 \mathrm{mg} / \mathrm{kg}$ higher than the total $\mathrm{Zn}$ mean concentration for worldwide soils $(55 \mathrm{mg} / \mathrm{kg}),(70$ $\mathrm{mg} / \mathrm{kg}$ ), and (64 mg/kg) as Alloway (2008), Kabata-Pendias (2011), and Kabata-Pendias and Mukherjee (2007) respectively, the source of $\mathrm{Zn}$ in the studied samples is anthropogenic. 
Table 2. Zinc average and concentration in agricultural soil of the study area

\begin{tabular}{|l|c|}
\hline Sample No. & Zn (mg/kg) \\
\hline L1 & 48.1 \\
\hline L2 & 52.8 \\
\hline L3 & 54.2 \\
\hline L4 & 58.6 \\
\hline L5 & 50.6 \\
\hline L6 & 48.1 \\
\hline L7 & 169.2 \\
\hline L8 & 83.5 \\
\hline L9 & 70.6 \\
\hline L10 & 73.4 \\
\hline Range & $48.1-169.2$ \\
\hline Average & 70.9 \\
\hline
\end{tabular}

Maximum content of zinc is observed in site L7 then L8, L9 and L10 samples (169.2, $83.5,70.6,73.4) \mathrm{in} \mathrm{mg} / \mathrm{kg}$ respectively, this increases are due to using wastewater for irrigation the field crops, this interpretation corresponds to the study of (Awadh and Al-Hamdani, 2019; Khan et al., 2014 and Khan et al., 2008), and use of agricultural fertilizers or vehicle traffic (Ozyazici et al., 2017), or enrichment by intensive agricultural activities for long time (Liu et al., 2019), but notice Zn concentration in L1, L2, L3, L4, L5, and L6 samples are lower than the content from the above mentioned samples $(48.1,52.8,54.2,58.6,50.6$, and 48.1) in $\mathrm{mg} / \mathrm{kg}$ respectively, that indicate these sampling sites are not under the exhibition of any anthropogenic or industrial source that increase $\mathrm{Zn}$ content in the soil.

The zinc concentrations in four kinds of vegetable samples for each location are listed in Table 3. Zinc total concentration in leafy vegetable samples ranges from 18.9-95.3 mg/kg, with mean concentration of $47.11 \mathrm{mg} / \mathrm{kg}$. In detail, $\mathrm{Zn}$ concentration ranged from 18.9-35.5 $\mathrm{mg} / \mathrm{kg}$ in celery, $41.3-66.1 \mathrm{mg} / \mathrm{kg}$ in basil, $47.9-95.3 \mathrm{mg} / \mathrm{kg}$ in cress, and 33.1-49.4 mg/kg in arugula samples. According to the results, the highest average of $\mathrm{Zn}$ was in Cress 67.73> Basil $52.53>$ Arugula $38.9>$ Celery $29.3 \mathrm{mg} / \mathrm{kg}$ (Table 3) and (Fig. 2), this increasing in $\mathrm{Zn}$ concentration is attributed to irrigation fields with wastewater (Ismail and Rashid, 2017), where the concentration of $\mathrm{Zn}$ in same or different type of vegetables are varied from one sampling location to another is dependent on the $\mathrm{Zn}$ concentration in sampling soil location (Mohamed et al., 2003), and ability of vegetable to absorb the zinc through their roots and transfer them to different parts of plant from soil (Kananke et al., 2015). 


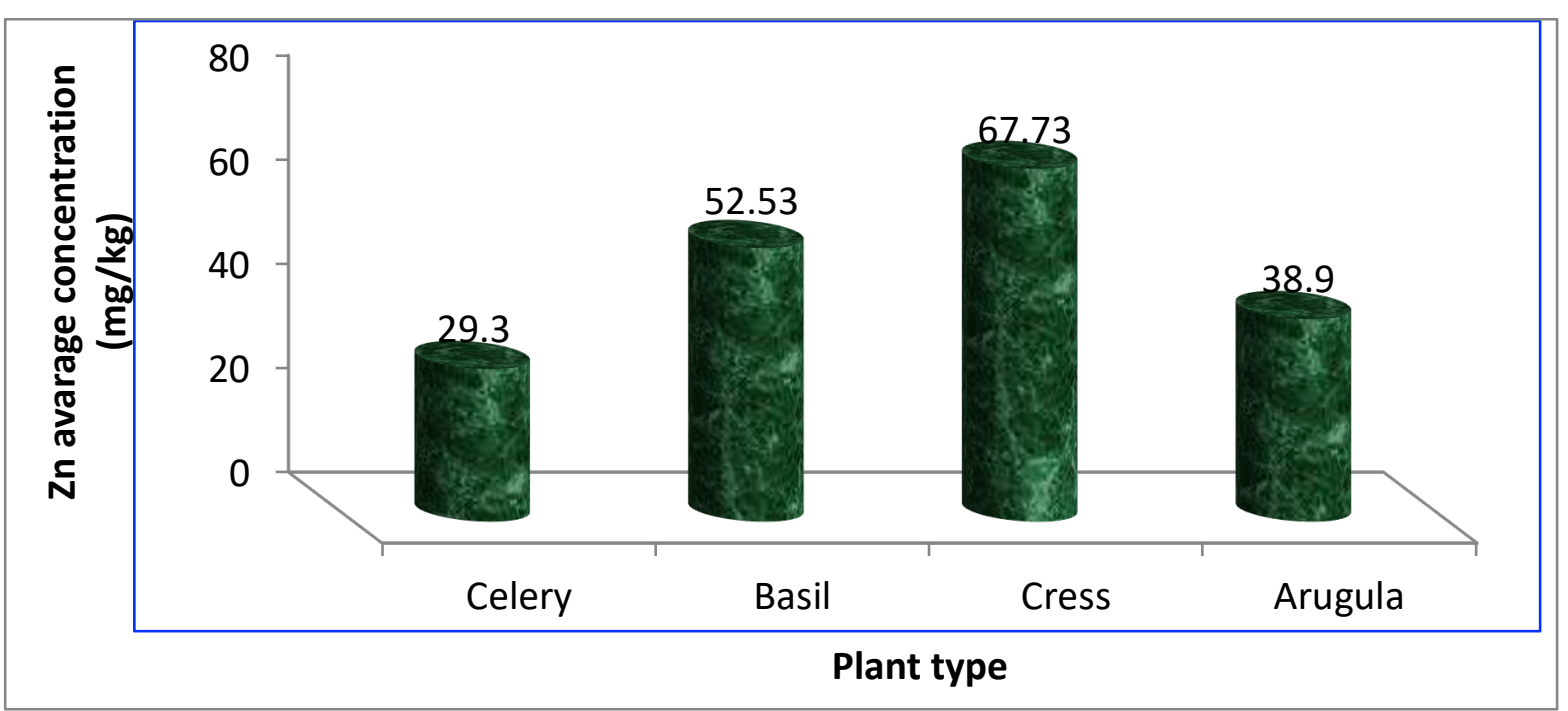

Fig. 2. Average zinc concentration of leafy vegetables in the study area

Table 3. Zinc concentration and transfer factor (TF) values of leafy vegetable in study area samples

\begin{tabular}{|c|c|c|c|c|c|c|}
\hline $\begin{array}{l}\text { Sample } \\
\text { No. }\end{array}$ & Plant type & $\begin{array}{l}\text { Zn concentration } \\
\text { in soil }(\mathbf{m g} / \mathbf{k g})\end{array}$ & $\begin{array}{c}\text { Symbol of } \\
\text { Sample }\end{array}$ & $\begin{array}{l}\text { Zn concentration } \\
\text { in plant }(\mathrm{mg} / \mathrm{kg})\end{array}$ & $\begin{array}{c}\text { Symbol of } \\
\text { Sample }\end{array}$ & TF \\
\hline 1 & Celery 1 & 52.8 & L2 & 35.5 & N1 & 0.672 \\
\hline 2 & Celery 2 & 169.2 & L7 & 18.9 & $\mathrm{~N} 2$ & 0.111 \\
\hline 3 & Celery 3 & 83.5 & L8 & 33.5 & N3 & 0.401 \\
\hline \multicolumn{2}{|c|}{ Av. } & & & 29.3 & & 0.395 \\
\hline 4 & Basil 1 & 52.8 & L2 & 50.2 & N4 & 0.950 \\
\hline 5 & Basil 2 & 169.2 & L7 & 66.1 & N5 & 0.390 \\
\hline 6 & Basil 3 & 83.5 & L8 & 41.3 & N6 & 0.494 \\
\hline \multicolumn{2}{|c|}{ Av. } & & & 52.53 & & 0.612 \\
\hline 7 & Cress 1 & 52.8 & L2 & 47.9 & N7 & 0.907 \\
\hline 8 & Cress 2 & 169.2 & L7 & 95.3 & $\mathrm{~N} 8$ & 0.563 \\
\hline 9 & Cress 3 & 83.5 & L8 & 60 & N9 & 0.718 \\
\hline \multicolumn{2}{|c|}{ Av. } & & & 67.73 & & 0.729 \\
\hline 10 & Arugula 1 & 52.8 & L2 & 49.4 & N10 & 0.935 \\
\hline 11 & Arugula 2 & 169.2 & L7 & 34.2 & N11 & 0.202 \\
\hline 12 & Arugula 3 & 83.5 & L8 & 33.1 & N12 & 0.396 \\
\hline \multicolumn{2}{|c|}{ Av. } & & & 38.9 & & 0.511 \\
\hline \multicolumn{2}{|c|}{ Range } & & & $18.9-95.3$ & & $0.111-0.950$ \\
\hline \multicolumn{2}{|c|}{ Total Av. } & & & 47.11 & & 0.562 \\
\hline
\end{tabular}

\section{Transfer Factor of Zinc in Leafy Vegetables}

Calculated transfer factor $(T F)$ values for Zinc in various leafy vegetables of the study area samples are varied between plant kinds (Table 3). The TF total value of $\mathrm{Zn}$ ranged from (0.1110.950), with total average (0.562) for all kinds of plant. $T F$ values ranged from 0.111-0.672 in celery, 0.390-0.950 in basil, 0.563-0.907 in cress, and 0.202-0.935 in arugula. Where record the highest average in transfer ability of zinc in cress and lower value is in celery ( $T F$ Cress $0.729>$ 
$T F$ Basil 0.612 $>T F$ Arugula 0.511 $>T F$ Celery 0.395) respectively, the difference depends on the plant type and their environment (Swasti Prabasiwi et al., 2020), and sampling site to another (Kananke et al., 2015).

The vegetable samples N4, N7, N10 that were growth on soil sample L2 (field opposite to $1 \mathrm{st}$ of March), $\mathrm{Zn}$ concentration reached $52.8 \mathrm{mg} / \mathrm{kg}$, from that observed is very near to concentration value in vegetables as basil 1 (N4=50.2 mg/kg); cress 1 (N7=47.9 mg/kg); arugula $1(\mathrm{~N} 10=49.4 \mathrm{mg} / \mathrm{kg})$, and the transfer factor values in the vegetable samples are around one $(\mathrm{TF} \sim 1)$, this indicates to uniformity in transfer of the zinc from soil to leafy vegetables in this site samples, and that convergence in concentration is depending on the properties of the soil in the sampling area and its environmental conditions (Rehman et al., 2017).

\section{Pollution Assessment of Zinc in Soils}

Pollution assessment indices of zinc in agricultural soil samples are shown in Table 4. All sample site is unpolluted with zinc, whose $I_{g e o}$ values ranged from $-1.02--0.22$, which is within the class $\left(I_{g e o} \leq 0\right)$, except in sample L7 the $I_{g e o}$ value for it was 0.8 , that is in class $\left(0<I_{g e o}<\right.$ 1), indicate unpolluted to moderately polluted site with $\mathrm{Zn}$ due to occurrence of wastewater.

Table 4. Geo-accumulation index $\left(I_{g e o}\right)$ and contamination factor $\left(C_{f}\right)$ values in studied soil samples

\begin{tabular}{|l|c|c|}
\hline Sample No. & $\boldsymbol{I}_{\text {geo }}$ & $\boldsymbol{C}_{\boldsymbol{f}}$ \\
\hline L1 & -1.02 & 0.74 \\
\hline L2 & -0.88 & 0.812307692 \\
\hline L3 & -0.84 & 0.833846154 \\
\hline L4 & -0.73 & 0.901538462 \\
\hline L5 & -0.94 & 0.778461538 \\
\hline L6 & -1.02 & 0.74 \\
\hline L7 & 0.8 & 2.603076923 \\
\hline L8 & -0.22 & 1.284615385 \\
\hline L9 & -0.46 & 1.086153846 \\
\hline L10 & -0.41 & 1.129230769 \\
\hline
\end{tabular}

While contamination factor with $\mathrm{Zn}$ results show the soil samples (L1, L2, L3, L4, L5, and L6) have $C_{f}$ value $(0.74,0.81,0.83,0.9,0.77$, and 0.74$)$ respectively, indicate low contamination level by $\mathrm{Zn}$ in this site $\left(C_{f}<1\right)$, and the sites (L7, L8, L9, L10) have $C_{f}$ value $(2.603,1.284,1.086$ and 1.129$)$ in class $\left(1 \leq C_{f}<3\right)$ with moderate contamination level by $\mathrm{Zn}$, where the highest $C_{f}$ value is recorded in L 7 sample, this increase is due to irrigation by waste water. 


\section{Health Risk Assessment of Zinc in Leafy Vegetables}

The THQ results for children and adults from zinc content in study area leafy vegetable samples for each type (Table 5). Where the THQ for zinc in celery for children was higher than the adults (THQ celery child > THQ celery adult), but generally the THQ values are less than one (THQ celery $<1$ ), that indicate the local population is not exposed to health effect from $\mathrm{Zn}$. Where THQ value for $\mathrm{Zn}$ in basil for children in sample N4 and N5 is 1.138 and 1.498 respectively, while for adults in sample N5 is 1.303 . THQ basil $>1$ indicate the children and adults in this samples are exposed to health effect from Zinc compared with another sample.

Table 5. THQ of zinc for children and adults in leafy vegetable

\begin{tabular}{|l|c|c|c|}
\hline Sample No. & Plant type & THQ child & THQ adult \\
\hline N1 & Celery 1 & 0.805 & 0.7 \\
\hline N2 & Celery 2 & 0.428 & 0.372 \\
\hline N3 & Celery 3 & 0.759 & 0.66 \\
\hline N4 & Basil 1 & 1.138 & 0.99 \\
\hline N5 & Basil 2 & 1.498 & 1.303 \\
\hline N6 & Basil 3 & 0.936 & 0.814 \\
\hline N7 & Cress 1 & 1.086 & 0.944 \\
\hline N8 & Cress 2 & 2.161 & 1.879 \\
\hline N9 & Cress 3 & 1.36 & 1.183 \\
\hline N10 & Arugula 1 & 1.12 & 0.974 \\
\hline N11 & Arugula 2 & 0.775 & 0.674 \\
\hline N12 & Arugula 3 & 0.75 & 0.652 \\
\hline
\end{tabular}

As well as THQ value for children and adults in cress samples (N7, N8 and N9) are greater than one (THQ child cress $>1$ ), that local population are exposed to health effect from zinc in that sites, except THQ for N7 sample adults is less than one. Regarding arugula sample N10 the THQ value for children is 1.120 , that exposed to the zinc create health effect, while THQ for another samples is smaller than one, that indicate $\mathrm{Zn}$ did not exposed any health effects for local population.

\section{CONCLUSIONS AND RECOMMENDATIONS}

This study examines the zinc concentration in the agricultural soils in which the leafy vegetables grow and these vegetables are consumed by local population in the Kirkuk city, by assessing pollution indexes on $\mathrm{Zn}$ content in the soil, and health risks of $\mathrm{Zn}$ that may cause in four kinds of leafy vegetables to consumer. The reason for increasing of zinc concentration in soil samples L7, L8, L9, and L10 (169.2, 83.5, 70.6, $73.4 \mathrm{mg} / \mathrm{kg})$ are mainly due to the drainage of waste water into Al Khassa River and field crops irrigated with this water then runoff to the soil, uses 
agricultural fertilizers, enrichment by intensive agricultural activities, and vehicle traffic as well. Pollution assessment result Igeo value is proved that was moderately polluted with $\mathrm{Zn}$ in sample L7 (0.8), and uncontaminated to moderately contaminated factor $C_{f}$ value for zinc in L7, L8, L9, and L10 samples $(2.603,1.284,1.086,1.129)$ respectively. While the $\mathrm{Zn}$ concentration in vegetable samples records the highest average in Cress 67.73> Basil 52.53> Arugula $38.9>$ Celery $29.3 \mathrm{in} \mathrm{mg} / \mathrm{kg}$ respectively, then this results corresponds to the transfer factor results ( $T F$ Cress $0.729>T F$ Basil 0.612 $>T F$ Arugula 0.511 $>T F$ Celery 0.395) in terms of the sequence of vegetable kinds, which is the reason for its increased content in celery compared with other type is the concentration of zinc in the soil, ability to transfer it, absorption it from the soils by roots, type of vegetables, and soil properties. Through an assessment the health risks of $\mathrm{Zn}$ on local population for both age groups via consumption leafy vegetable studied samples, results show the THQ values for children (THQ child $>1$ ) in samples N4, N5, $\mathrm{N} 7, \mathrm{~N} 8, \mathrm{~N} 9, \mathrm{~N} 10$ except N1, N2, N3, N6 and for adult THQ values (THQ adult $>1$ ) in samples $\mathrm{N} 5, \mathrm{~N} 8, \mathrm{~N} 9$ except N1, N2, N3, N4, N6, N7, N10 they are exposed to different health effects. Sum up and suggest the recommendations from the results obtained, it shall not be irrigated vegetable fields with wastewater that source from Khassa River, and reduce the use of fertilizers, that in order to increase the zinc concentration which leads it to absorption by studied vegetables and effect on the human health of local population.

\section{ACKNOWLEDGMENTS}

The authors are very grateful to the Editor in Chief Prof. Dr. Salih M. Awadh, the Secretary of Journal Mr. Samir R. Hijab and the Technical Editor Dr. Heba S. Al-Mimar for their great efforts and valuable comments.

\section{REFERENCES}

Adedokun, A. H., Njoku, K. L., Akinola, M. O., Adesuyi, A. A. and Jolaoso, A. O., 2016. Potential human health risk assessment of heavy metals intake via consumption of some leafy vegetables obtained from four market in Lagos Metropolis, Nigeria. Journal of Applied Sciences and Environmental Management, 20(3): 530-539.

Adimalla, N., and Wang, H., 2018. Distribution, contamination, and health risk assessment of heavy metals in surface soils from northern Telangana, India. Arabian Journal of Geosciences, 11(21): 684.

Akande, F. O., and Ajayi, S. A., 2017. Assessment of heavy metals level in soil and vegetables grown in periurban farms around Osun State and the associated human health risk. International Journal of Environment, Agriculture and Biotechnology, 2(6): 239024.

Akhtar, M., Yousaf, S., Sarwar, N. and Hussain, S., 2019. Zinc biofortification of cereals-role of phosphorus and other impediments in alkaline calcareous soils. Environmental Geochemistry and Health, 1-15.

Al-Hamdani, J. A. J, Awadh, S. M., and Ibrahim, O. S., 2016. Geochemical partitioning of heavy metals in urban soil, Kirkuk, Iraq. Iraqi Geological Journal., 39-49.

Alloway, B. J., 2013. Sources of heavy metals and metalloids in soils. In Heavy metals in soils, Springer, Dordrecht, 11-50.

Alloway, B. J., 2008. Zinc in soils and crop nutrition. Published by IZA and IFA. Brussels, Belgium and Paris, France, 135. 
Awadh, S. M., and Al-Hamdani, J. A., 2019. Urban geochemistry assessment using pollution indices: a case study of urban soil in Kirkuk, Iraq. Environmental Earth Sciences, 78(20): 587.

Baltas, H., Sirin, M., Gökbayrak, E. and Ozcelik, A. E., 2019. A case study on pollution and a human health risk assessment of heavy metals in agricultural soils around Sinop province, Turkey. Chemosphere, 241, 125015.

Cervantes-Trejo, A., Pinedo-Álvarez, C., Santellano-Estrada, E., Cortes-Palacios, L. and Rentería-Villalobos, M., 2018. Distribution of chemical species in the water-soil-plant (carya illinoiensis) system near a mineralization area in Chihuahua, Mexico-health risk implications. International Journal of Environmental Research and Public Health, 15(7): 1393.

Chasapis, C. T., Loutsidou, A. C., Spiliopoulou, C. A. and Stefanidou, M. E., 2012. Zinc and human health: an update. Archives of Toxicology, 86(4): 521-534.

Chien, L. C., Hung, T. C., Choang, K. Y., Yeh, C. Y., Meng, P .J., Shieh, M. J. and Han, B. C., 2002. Daily intake of TBT, $\mathrm{Cu}, \mathrm{Zn}, \mathrm{Cd}$ and as for fishermen in Taiwan. Science of The Total Environment, 285(1-3), 177185.

Cui, Y. J., Zhu, Y. G., Zhai, R. H., Chen, D. Y., Huang, Y. Z., Qiu, Y. and Liang, J. Z., 2004. Transfer of metals from soil to vegetables in an area near a smelter in Nanning, China. Environment International, 30(6): 785-791.

Das, S. and Green, A., 2016. Zinc in Crops and Human Health. in Biofortification of Food Crops (31-40). Springer, New Delhi.

FAO/WHO, 2001. Human vitamin and mineral requirements. Report of a joint FAO/WHO expert consultation, Bangkok, Thailand. Food and Nutrition Division, FAO, Rome, 286.

Gupta, N., Ram, H., and Kumar, B., 2016. Mechanism of Zinc absorption in plants: uptake, transport, translocation and accumulation. Reviews in Environmental Science and Bio/Technology, 15(1): 89109.

Gupta, N., Yadav, K. K., Kumar, V., Kumar, S., Chadd, R. P., and Kumar, A., 2019. Trace elements in soilvegetables interface: Translocation, bioaccumulation, toxicity and amelioration-A review. Science of the Total Environment, 651: 2927-2942.

Harrison, R. M. and Chirgawi, M. B., 1989. The assessment of air and soil as contributors of some trace metals to vegetable plants I. Use of a filtered air growth cabinet. Science of the Total Environment, 83(1-2), 13-34.

Hefferon, K., 2019. Biotechnological approaches for generating zinc-enriched crops to combat malnutrition. Nutrients, 11(2): 253.

Heiserman, D. L., 1992. Element 30: Zinc. Exploring Chemical Elements and their Compounds, New York, 124.

Imseng, M., Wiggenhauser, M., Müller, M., Keller, A., Frossard, E., Wilcke, W. and Bigalke, M., 2019. The fate of $\mathrm{Zn}$ in agricultural soils: a stable isotope approach to anthropogenic impact, soil formation, and soilplant cycling. Environmental science \& technology, 53(8): 4140-4149.

Islam, M. S., Ahmed, M. K., Habibullah-Al-Mamun, M., and Masunaga, S., 2014. Trace metals in soil and vegetables and associated health risk assessment. Environmental monitoring and assessment, 186(12): 8727-8739.

Ismail, S. A., and Rashid, Sh. M., 2017. Health risk assessment of heavy metals for population via consumption of vegetables collected from Khassa River, Kirkuk city, Northern Iraq. International Journal of Current Research and Academic Review, 5(1): 104-110.

Jolly, Y. N., Islam, A., and Akbar, S., 2013. Transfer of metals from soil to vegetables and possible health risk assessment. SpringerPlus, 2(1): 385.

Kabata-Pendias, A., and Mukherjee, A. B., 2007. Trace elements from soil to human. Springer Science \& Business Media, p. 550.

Kabata-Pendias, A., 2011. Trace elements in soils and plants/fourth editions. CRC Taylor and Francis Group, Boca Raton, p.505.

Kananke, T. C., Wansapala, J., and Gunaratne, A., 2015. Pb and Cr contaminations of irrigation water, soils and green leafy vegetables collected from different areas of Colombo District, Sri Lanka. Pakistan Journal of Nutrition 14(9): 593-602.

Khan, M. U., Muhammad, S., and Malik, R. N., 2014. Potential risk assessment of metal consumption in food crops irrigated with wastewater. Clean-Soil, Air, Water, 42(10):1415-1422.

Khan, S., Cao, Q., Zheng, Y.M., Huang, Y.Z. and Zhu, Y.G., 2008. Health risks of heavy metals in contaminated soils and food crops irrigated with wastewater in Beijing, China. Environmental pollution, 152(3): 686692.

Kooner, R., Mahajan, B. V. C., and Dhillon, W. S., 2014. Heavy metal contamination in vegetables, fruits, soil and water a critical review. International Journal of Agriculture, Environment and Biotechnology, 7(3), 603-612. 
Liu, M., Han, Z. and Yang, Y., 2019. Accumulation, temporal variation, source apportionment and risk assessment of heavy metals in agricultural soils from the middle reaches of Fenhe River basin, North China. RSC advances, 9(38):21893-21902.

Loska, K., Wiechuła, D., and Korus, I., 2004. Metal contamination of farming soils affected by industry. Environment international, 30(2):159-165.

Mičijević, A., Šukalić, A. and Leto, A., 2019, June. non-cancerogenic risk to human health with $\mathrm{Pb}, \mathrm{Cu}$, and $\mathrm{Zn}$ intake from soil in the area of Herzegovina. In International Conference of New Technologies, Development and Applications, Springer, 633-671.

Mohamed, A. E., Rashed, M. N. and Mofty, A., 2003. Assessment of essential and toxic elements in some kinds of vegetables. Ecotoxicology and environmental safety, 55(3): 251-260.

Müller, G., 1986. Schadstoffe in sedimenten-sedimente als schadstoffe. Mitt, Österreichische Geologische Gesellschaft, 79:107-126.

Noulas, C., Tziouvalekas, M. and Karyotis, T., 2018. Zinc in soils, water and food crops. Journal of Trace Elements in Medicine and Biology, 49: 252-260.

Nu, N. T, Duong, N. T, Son, B. T and Thinh, P. H., 2020. Investigation of salt, alum content in soft soils and their effects on soil properties: Case study in coastal areas of Vietnam. Iraqi geological Journal, 53 (2A):19-34.

Olowoyo, J. O., Van Heerden, E., Fischer, J. L. and Baker, C., 2010. Trace metals in soil and leaves of Jacaranda mimosifolia in Tshwane area, South Africa. Atmospheric Environment, 44(14):1826-1830.

Ozyazici, M. A., Dengiz, O., and Ozyazici, G., 2017. Spatial distribution of heavy metals density in cultivated soils of Central and East Parts of Black Sea Region in Turkey. Eurasian Journal of Soil Science, 6(3): 197.

Proshad, R., Kormoker, T., Islam, M. S., and Chandra, K., 2019. Potential health risk of heavy metals via consumption of rice and vegetables grown in the industrial areas of Bangladesh. Human and Ecological Risk Assessment: An International Journal, 921-943.

Rai, P. K., Lee, S. S., Zhang, M., Tsang, Y. F. and Kim, K. H., 2019. Heavy metals in food crops: Health risks, fate, mechanisms, and management. Environment International, 125, 365-385.

Rehman, Z. U., Sardar, K. H. A. N., Shah, M. T., Brusseau, M. L., Khan, S. A. and Mainhagu, J., 2017. Transfer of heavy metals from soils to vegetables and associated human health risks at selected sites in Pakistan. Pedosphere, 28(4): 666-679.

Reimann, C., en Caritat , P.D., 1998. Chemical Elements in The Environment: Factsheets for The Geochemist and Environmental Scientist. Springer Science, 404.

Ren, Z., Xiao, R., Zhang, Z., Lv, X. and Fei, X., 2019. Risk assessment and source identification of heavy metals in agricultural soil: a case study in the coastal city of Zhejiang Province, China. Stochastic Environmental Research and Risk Assessment, 33(11-12): 2109-2118.

Swasti Prabasiwi, D., Murniasih, S. and Rozana, K., 2020. Transfer factor as indicator of heavy metal content in plants around adipala steam power plant. JPhCS, 1436(1): 012133.

Wang, X., Sato, T., Xing, B. and Tao, S., 2005. Health risks of heavy metals to the general public in Tianjin, China via consumption of vegetables and fish. Science of the total environment, 350(1-3): 28-37.

Wedepohl, K. H., 1995. The composition of the continental crust. Geochimica et cosmochimica Acta, 59(7): 12171232.

WHO/FAO, 2017. Joint report, Food standard programs Codex committee on contaminants in foods (CF/11 INF/1). Rome: Author, 1-162.

Wu, J., Lu, J., Li, L., Min, X. and Luo, Y., 2018. Pollution, ecological-health risks, and sources of heavy metals in soil of the northeastern Qinghai-Tibet Plateau. Chemosphere, 201: 234-242. 